\title{
Evaluation of Different Genotypes of Tuberose (Polianthes tuberosa L.) for Growth, Flowering and Yield Characters
}

\author{
Bindiya C. Naik, B. S. Kamble, Shantappa Tirakannanavar* and Savita Parit \\ Department of Floriculture and Landscape Architecture, Kittur Rani Channamma College of \\ Horticulture (UHS Bagalkot, Karnataka), Arabhavi-591 218, India \\ *Corresponding author
}

\section{A B S T R A C T}

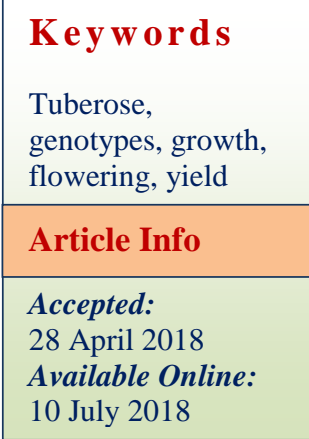

\section{Introduction}

With the advancement of human civilization, the demand for flowers is increasing day by day throughout the world. Among the wide varieties of cultivated flowers, tuberose (Polianthes tuberosa L.), is one of the most important tropical ornamental bulbous flowering plants cultivated for production of long lasting flower spikes. It belongs to the family Amaryllidaceae having haploid chromosome number of 30 . The generic name Polianthes is derived from Greek word "polios" meaning shiny or white and "anthos" meaning flower. Tuberose is native to Mexico from where it is spread to different parts of the world during $16^{\text {th }}$ century. This plant being the tuberous hyacinth as distinguished from the bulbous hyacinth, the name thus is 'tuber ose', not 'tube - rose'. Tuberose is half hardy, perennial bulbous plant. Bulbs are made of scales and leaf bases and stem remain concealed within scales. Roots are adventious and shallow. Tuberose inflorescences (spikes) bear $25 \pm 10$ pairs of florets which open acropetally (i.e., from base to top of the spike). Flowers have a funnel shaped perianth and are fragrant, waxy white, about $25 \mathrm{~mm}$ long. Stamens are six in number, ovary 3 locular, ovules numerous and fruits are capsule (Anon., 2006).

Polianthes genus contains three types of flowers. One of them is single flower type 
which is female fertile used in perfumery industry and breeding programme as female parent. The other two are semi-double and double flower types and generally used as cut flower. Due to their lingering delightful fragrance and charm, these flowers are adorned with vernacular names in India like Gulchari and Gulshabbo in Hindi, Rajanigandha in Bengali, Sukandaraji and Nelasampangi in Telagu, Nilasampangi in Tamil and as Sugandharaja in Kannada (Jawaharlal et al., 2006). In India its commercial cultivation is confined to Andhra Pradesh, Karnataka, Chattisgarh, Odisha and Tamil Nadu. The performance of any crop or variety largely depends upon its genetic makeup and climatic condition of the region under which they are grown. As a result, cultivars which perform well in one region may not perform well in other regions of varying climatic conditions. Hence, it is very much necessary to collect and evaluate all the available genotypes in order to select suitable and high yielding genotypes for a particular region. Considering the potentiality of this crop, it is very much necessary to find out the varieties suitable to a particular region. Growth, flowering, vase life and shelf life are the important characters to be considered for the evaluation of genotypes of tuberose.

\section{Materials and Methods}

The present investigation was carried out in the field of Department of Floriculture and Landcape Architecture, Kittur Rani Channamma College of Horticulture, Arabhavi, Gokak Taluk, Belgavi district of Karnataka during the period from August 2015 to January 2016 to study the performance of eight tuberose genotypes for growth, flowering and yield characters. Healthy and disease free bulbs of eight tuberose genotypes were used in this experiment. The bulbs of genotypes Shringar, Prajwal, Suvasini, Pearl Double, Calcutta
Single, Mexican Single and Vaibhav, were collected from the Department of Floriculture and Landscape Architecture, Kittur Rani Channamma College of Horticulture, Arabhavi; and another genotype Arka Nirantara is collected from Indian Institute of Horticulture Research, Bengaluru. Altogether there were eight treatments (genotypes) and were replicated thrice. The land was brought to fine tilth by repeated ploughing and harrowing. Ridges were opened at a spacing of $30 \mathrm{~cm}$. The plots of required size were prepared. Well decomposed farm yard manure was applied before the land preparation at the rate of 25 tonnes per hectare and mixed well into the soil.

Healthy bulbs were planted on ridges at a spacing of $30 \times 30 \mathrm{~cm}$ and light irrigation was given immediately after planting. Gap filling was done whenever it was necessary. Five plants were selected at random within the net plot area of each treatment and replication for the purpose of recording the observations. The mean value of the data recorded from five plants in each treatment of the three replications was taken to represent a particular variety with respect to a character. The data on various biometric parameters recorded during the crop growth period of this study was subjected to statistical analysis as per the procedures suggested by Panse and Sukhatme (1969). The results are discussed at one and five per cent probability level.

\section{Results and Discussion}

\section{Growth parameters}

Among the different genotypes of tuberose the number of days taken for 50 per cent sprouting, plant height and leaf area are presented in Table 1. Number of days taken for 50 per cent bulbs to sprout varied significantly among the genotypes which range from 5.46 to 10.04 days. Among the 
genotypes, Prajwal was the earliest to reach 50 per cent sprouting (5.46 days) and was statistically on par with the genotype Vaibhav (5.70 days), while the genotype Arka Nirantara took more number of days for sprouting (10.04 days). The variation in sprouting of bulbs among different genotypes could be attributed to their differences in genetic makeup. The variations in time taken for sprouting among the tuberose genotypes have been reported previously by Ahmed et al., (2002) in gladiolus and Singh and Singh (2013) in tuberose.

Significant differences were found among the genotypes with respect to plant height at 30 days after planting (DAP). The genotype Prajwal recorded maximum plant height $(23.73 \mathrm{~cm})$ and was statistically on par with genotype Shringar $(21.00 \mathrm{~cm})$ followed by Suvasini $(20.10 \mathrm{~cm})$. The genotype Arka Nirantara $(13.91 \mathrm{~cm})$ recorded minimum plant height followed by genotype Pearl Double $(14.68 \mathrm{~cm})$. The genotype Prajwal recorded maximum plant height $(35.33 \mathrm{~cm})$ at 60 DAP and was statistically on par with genotype Shringar $(35.06 \mathrm{~cm})$. The genotype Arka Nirantara $(23.00 \mathrm{~cm})$ recorded minimum plant height at 60 DAP. Plant height at 90 and 120 DAP recorded maximum $(44.01 \mathrm{~cm})$ and $(65.28 \mathrm{~cm})$ in Prajwal respectively. The genotype Arka Nirantara recorded minimum plant height at 90 and 120 DAP. Maximum plant height at 150 days after planting was recorded in Prajwal $(65.28 \mathrm{~cm})$ and was statistically on par with genotype Shringar $(62.00 \mathrm{~cm})$. The genotype Arka Nirantara recorded minimum plant height $(44.25 \mathrm{~cm})$. At all stages of plant growth the plant height significantly varied among the different tuberose genotypes. In general the growth of all the genotypes increased gradually as the days advanced. Similar variation in plant height was also reported previously by Shiramagond (1997) in gladiolus and Biswas et al., (2002) in tuberose.
With respect to leaf area the significant differences were recorded among the genotypes, maximum leaf area was recorded in genotype Prajwal $\left(471.06 \mathrm{~cm}^{2}\right)$ followed by the genotype Shringar $\left(257.37 \mathrm{~cm}^{2}\right)$.

The minimum leaf area was recorded in genotype Arka Nirantara $\left(74.93 \mathrm{~cm}^{2}\right)$. Higher leaf area in the genotypes was due to increased number of leaves. Due to lesser number of leaves and smaller size of leaves resulted in minimum leaf area in Arka Nirantara. Since genotypes varied for their number of leaves accordingly their leaf area was also varied. Variation in leaf area in different genotypes was also reported previously by Deepti and Anil (2005) in marigold.

\section{Flowering parameters}

The data pertaining to flowering parameters like days taken for emergence of spike, $50 \%$ flowering, duration of flowering and days taken for first harvest in different tuberose genotypes are represented in Table 2 . Significant differences were noticed among the genotypes for number of days required for first spike emergence and the range was from 78.87 to 95.34 days. The least number of days required for first spike emergence is in genotype Prajwal (73.03), which was statistically on par with the genotype Shringar (79.58) followed by genotypes Vaibhav (80.62), Suvasini (82.56), Mexican Single (85.19) and Pearl Double (85.40), while genotype Arka Nirantara took more number of days (95.34) for spike emergence. Genotype Prajwal was the earliest in emergence of spike followed by genotypes Shringar, Vaibhav and Suvasini. However the delayed spike initiation was observed in Arka Nirantara. The variations may be attributed to the fact that the performance of a genotype may vary with the climatic conditions prevailing in particular area. Similar variations were also reported by Biswas et al., (2002) in tuberose. 
Table.1 Days taken for $50 \%$ sprouting, plant height $(\mathrm{cm})$ and leaf area $\left(\mathrm{cm}^{2}\right)$ in different genotypes of tuberose

\begin{tabular}{|c|c|c|c|c|c|c|c|c|}
\hline \multirow{2}{*}{\multicolumn{2}{|c|}{ Genotypes }} & \multirow{2}{*}{$\begin{array}{c}\text { Days taken } \\
\text { for } 50 \% \\
\text { sprouting }\end{array}$} & \multicolumn{5}{|c|}{ Pant height at different DAP } & \multirow[t]{2}{*}{ Leaf area } \\
\hline & & & 30 & 60 & 90 & 120 & 150 & \\
\hline $\mathrm{G}_{1}$ & Shringar & 5.82 & 21.00 & 35.06 & 43.52 & 62.00 & 73.22 & 257.37 \\
\hline $\mathrm{G}_{2}$ & Suvasini & 6.86 & 20.10 & 30.43 & 41.51 & 58.66 & 70.00 & 187.27 \\
\hline $\mathrm{G}_{3}$ & Mexican Single & 7.85 & 17.53 & 27.26 & 37.89 & 56.42 & 64.32 & 165.46 \\
\hline $\mathrm{G}_{4}$ & Prajwal & 5.46 & 23.73 & 35.33 & 44.01 & 65.28 & 77.66 & 471.07 \\
\hline $\mathrm{G}_{5}$ & Calcutta Single & 7.81 & 16.30 & 26.96 & 37.30 & 55.60 & 63.40 & 109.29 \\
\hline $\mathrm{G}_{6}$ & Pearl Double & 7.52 & 14.68 & 25.98 & 34.46 & 51.80 & 57.25 & 97.27 \\
\hline $\mathrm{G}_{7}$ & Vaibhav & 5.70 & 15.51 & 26.49 & 36.75 & 52.97 & 62.65 & 211.88 \\
\hline $\mathrm{G}_{8}$ & Arka Nirantara & 10.04 & 13.91 & 23.82 & 33.06 & 44.25 & 54.68 & 74.93 \\
\hline & S.Em. \pm & 0.23 & 1.24 & 1.37 & 1.12 & 1.81 & 2.06 & 6.10 \\
\hline & C.D. @ 5 \% & 0.71 & 3.77 & 4.18 & 3.41 & 5.49 & 6.27 & 18.52 \\
\hline
\end{tabular}

DAP: Days after planting

Table.2 Days taken for emergence of spike, $50 \%$ flowering, Duration of flowering and days taken for first harvest in different genotypes of tuberose

\begin{tabular}{|l|l|c|c|c|c|}
\hline Genotypes & $\begin{array}{c}\text { Days for } \\
\text { emergence } \\
\text { of spike }\end{array}$ & $\begin{array}{c}\text { Days to 50 } \\
(\%) \\
\text { flowering }\end{array}$ & $\begin{array}{c}\text { Duration of } \\
\text { flowering } \\
\text { (days) }\end{array}$ & $\begin{array}{c}\text { Days taken } \\
\text { for first } \\
\text { harvesting }\end{array}$ \\
\hline $\mathbf{G}_{1}$ & Shringar & 79.58 & 109.40 & 20.40 & 119.08 \\
\hline $\mathbf{G}_{2}$ & Suvasini & 82.56 & 111.21 & 28.06 & 126.02 \\
\hline $\mathbf{G}_{3}$ & Mexican Single & 85.19 & 112.70 & 8.00 & 125.07 \\
\hline $\mathbf{G}_{4}$ & Prajwal & 78.87 & 108.72 & 25.66 & 118.95 \\
\hline $\mathbf{G}_{5}$ & Calcutta Single & 92.74 & 122.63 & 9.80 & 135.03 \\
\hline $\mathbf{G}_{6}$ & Pearl Double & 85.40 & 118.30 & 17.60 & 128.02 \\
\hline $\mathbf{G}_{7}$ & Vaibhav & 80.62 & 110.29 & 22.73 & 122.93 \\
\hline $\mathbf{G}_{8}$ & Arka Nirantara & 95.34 & 125.93 & 10.88 & 137.57 \\
\hline & S.Em. \pm & $\mathbf{2 . 5 7}$ & $\mathbf{3 . 4 2}$ & $\mathbf{0 . 6 3}$ & $\mathbf{3 . 6 7}$ \\
\hline & C.D. @ 5 \% & $\mathbf{7 . 7 9}$ & $\mathbf{1 0 . 3 9}$ & $\mathbf{1 . 9 1}$ & $\mathbf{1 1 . 1 3}$ \\
\hline
\end{tabular}


Table.3 Loose flower yield, number of bulbs \& bulblets per plant and bulb yield of different genotypes of tuberose

\begin{tabular}{|c|c|c|c|c|c|c|c|}
\hline \multirow{2}{*}{\multicolumn{2}{|c|}{ Genotypes }} & \multicolumn{2}{|c|}{ Loose flower yield } & \multirow{2}{*}{$\begin{array}{c}\text { Number } \\
\text { of bulbs } \\
\text { per } \\
\text { plant }\end{array}$} & \multirow{2}{*}{$\begin{array}{c}\text { Number } \\
\text { Bulblets } \\
\text { per } \\
\text { plant }\end{array}$} & \multicolumn{2}{|c|}{ Bulb yield } \\
\hline & & $\begin{array}{c}\text { Per } \\
\text { plant (g) }\end{array}$ & $\begin{array}{c}\text { Per } \\
\text { hectare }(\mathbf{t})\end{array}$ & & & $\begin{array}{c}\text { Per } \\
\text { plant (g) }\end{array}$ & $\begin{array}{c}\text { Per } \\
\text { hectare }(t)\end{array}$ \\
\hline$\overline{\mathbf{G}_{1}}$ & Shringar & 137.79 & 16.52 & 7.34 & 5.26 & 12.86 & 1.59 \\
\hline$\overline{\mathbf{G}_{2}}$ & Suvasini & 146.24 & 17.17 & 8.36 & 5.31 & 17.57 & 2.13 \\
\hline $\mathbf{G}_{3}$ & Mexican Single & 96.09 & 11.30 & 6.53 & 4.69 & 11.78 & 1.19 \\
\hline $\mathbf{G}_{4}$ & Prajwal & 169.95 & 19.97 & 9.61 & 6.82 & 15.76 & 1.84 \\
\hline $\mathbf{G}_{5}$ & Calcutta Single & 114.06 & 13.75 & 5.53 & 3.45 & 9.34 & 1.08 \\
\hline$\overline{G_{6}}$ & Pearl Double & 125.84 & 14.73 & 6.84 & 2.62 & 10.78 & 1.25 \\
\hline$\overline{\mathbf{G}_{7}}$ & Vaibhav & 158.30 & 18.66 & 7.44 & 3.09 & 12.41 & 1.41 \\
\hline$\overline{G_{8}}$ & Arka Nirantara & 70.29 & 8.23 & 4.37 & 2.30 & 6.08 & 1.05 \\
\hline & 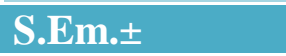 & 4.32 & 0.43 & 0.20 & 0.14 & 0.34 & 0.03 \\
\hline & D. @ $5 \%$ & 13.10 & 1.33 & 0.62 & 0.42 & 1.06 & 0.12 \\
\hline
\end{tabular}

Among the different genotypes the number of days required for 50 per cent flowering was ranged from 108.72 to 125.93 days. The least number of days (108.72) required for 50 per cent flowering was noticed in genotype Prajwal, which was statistically on par with genotype Shringar (109.40) followed by genotypes Vaibhav (110.29), Suvasini (111.21), Mexican Single (112.7) and Pearl Double (118.3). While genotype Arka Nirantara took more number of (125.93) days for $50 \%$ flowering. Significant differences were noticed for duration of flowering and the range was from 8.00 to 28.06 days. The genotype Suvasini recorded maximum duration (28.06 days) for flowering and was statistically on par with genotype Vaibhav (22.73 days) and minimum duration (8.00 days) was observed in genotype Mexican Single. Among the different genotypes the range for the number of days required for first harvest was from 118.95 to 137.57 days. The genotype Prajwal was early to reach harvest (118.95) and it was on par with genotype Shringar (116.08) followed by genotypes Vaibhav (122.93), Mexican Single (125.07), Suvasini (126.02) and Pearl Double (128.02). While genotype Arka Nirantara took more number of (137.57) days for first harvest. Earliness for the character, number of days taken for $50 \%$ flowering and days taken for first harvest was observed in genotype Prajwal, whereas delayed response was observed in genotype Arka Nirantara. Minimum duration of flowering was observed in Mexican Single and Calcutta Single, while, maximum duration was observed in Prajwal. Similar results were also reported by Ramachandrudu and Thangam (2009) in tuberose.

\section{Yield parameters}

The data on loose flower yield, number of bulbs per plant, number of bulblets per plant and bulb yield was presented in Table 3 . The genotypes showed significant difference with respect to loose flower yield per plant. The range observed was between 70.29 to 169.95 g. The genotype Prajwal recorded maximum loose flower yield per plant $(169.95 \mathrm{~g})$ and was statistically on par with genotype Vaibhav $(158.30 \mathrm{~g})$. The minimum loose flower yield per plant was recorded in genotype Arka Nirantara (70.29 g). With respect to loose flower yield per hectare 
genotype Prajwal recorded maximum yield (19.97 t) and was statistically on par with genotype Vaibhav (18.66 t). The minimum loose flower yield per hectare was recorded in genotype Arka Nirantara $(8.23 \mathrm{t})$. The more production of flowers has direct relation with better vegetative growth of the plants, which leads to the production of more number of spikes per plant as well as more number of florets per spike; in turn it results in increased loose flower yield per plant and per hectare. Similar variation in loose flower yield was also reported previously by Irulappan et al., (1980), Patil et al., (1987), Meenakshi and Niranjanmurthy (1997) and Gupta et al., (2004) in tuberose.

The range observed for number of bulbs per plant was between 4.37 to 9.61 . The genotype Prajwal recorded maximum number of bulbs per plant (9.61), which was statistically on par with genotype Suvasini (8.36). The least number of bulbs was produced in genotype Arka Nirantara (4.37). W With respect to number of bulblets per plant the range observed was between 2.30 to 6.82 bulblets per plant. The genotype Prajwal recorded maximum number of bulblets per plant (6.82), which was statistically on par with genotype Suvasini (5.31) followed by genotype Shringar (5.26). The least number of bulblets per plant (2.30) was produced in genotype Arka Nirantara.

The data pertaining to bulb yield per plant (g) showed significant difference and the range observed was between 8.54 to $18.01 \mathrm{~g}$. The genotype Suvasini recorded maximum bulb yield per plant (18.01 g), which was statistically on par with genotype Prajwal $(15.76 \mathrm{~g})$. The genotype Arka Nirantara recorded minimum bulb yield per plant $(8.54$ g). With respect to bulb yield per hectare the genotype Suvasini recorded maximum (2.13 t), followed by genotype Prajwal (1.84 t). The genotype Arka Nirantara recorded minimum bulb yield per hectare $(1.05 \mathrm{t})$. The genotype Suvasini and Prajwal recorded the maximum number bulbs, bulblets and the least was observed in genotype Arka Nirantara. Genotype with more number of leaves has improved photosynthetic activity, source and sink relationship and accumulates more carbohydrates which improve the bulb and bulblet yield per plant, per plot and per hectare. Similar variation in bulb yield was also reported previously by Krishnamoorthy (2014) and Singh et al., (2013) in tuberose.

From the results of investigation it was concluded that the correlation studies revealed that plant height exhibited positive correlation with number of spikes per plant, spike length and number of leaves. Loose flower yield found to be positively correlated with number of leaves per plant, spike length, number of spikes per plant, 100 flowers weight, bulb diameter and plant height. There exist a positive correlation between flower diameter and looser flower yield per plant. Performance in terms of growth, yield and flower quality of any flower crop is influenced by various factors like variety, season, environment etc. Among these factors, genotypes themselves contribute much to their performance. Further, the performance of varieties of any crop differs from one region to another region. Hence, selection of genotype is an important criteria for successful cultivation of any crop.

\section{References}

Ahmed, M. J., Akbar, Z., Kosar, N. and Khan, A, K., 2002, Introduction and evaluation of exotic gladiolus (Gladiolus grandiflorus L.). Asian J. Plant Sci., 1 (3): 560-562.

Anonymous, 2006, Tuberose, Int. Floricul. Hand Book, EIRI Consultants and Engineers, Indian Institute of Consultants, New Delhi, pp. 517-541. 
Biswas, B., Naveen, K. P. and Bhattacharjee, S. K., 2002, Tuberose. AICRP on Floriculture, Technical Bulletin, 21: 56.

Deepti, S. and Anil, K. S., 2005, Evaluation of French marigold (Tagetes patula L.) and wild marigold (Tagetes minuta L.) under submountaneous tarai conditions. J. Orn. Hort., 8 (2): 134-136.

Gupta, N. K., Rakesh, K. S. and Mahobla, R., 2004, Performance of tuberose (Polianthes tuberosa L.) cultivars and their vase life in Malwa region of Madhya Pradesh. National Symposium on Recent Trends and Future Strategies in Orn. Hort, Dharwad. Pp. 19.

Irulappan, I., Doraipandian, A. and Muthuswamy. S., 1980, Varietal evaluation in tuberose (Polianthes tuberosa L.), National Seminar on Production of Technology for Commercial Flower Crops, Coimbatore, India. Tamil Nadu Agric. Univ., Pp. 67-70.

Jawaharlal, M., Arumugam, T., Bhattacharjee, S. K. and Vijayakumar, 2006, Tuberose. Adv. Orn. Hort., Pointer Publishers, Jaipur, 3: 107-132.

Krishnamoorthy, V., 2014, Assessment of tuberose (Polianthes tuberosa L.) varieties for growth and yield characters. The Asian J. Hort., 9 (2): 515-517.
Meenakshi, S. and Niranjanmurthy, 1997, High yielding tuberose (Polianthes tuberosa L.) hybrid 'Shringar' for concrete. Indian Perfumer, 41 (4): 157161.

Panse, V. S. and Sukhatme, P. V., 1969, Statistical methods for agricultural workers $\left(2^{\text {nd }}\right.$ edi), Indian council of Agriculture Research, New Delhi, p.381.

Patil, J. D., Patil, B. A., Chougule, B. B. and Bhat, N. R., 1987, Performance of different tuberose (Polianthes tuberosa L.) under Pune conditions. Curr. Res., 3 (1): 118-119.

Ramachandrudu, K. and Thangam, 2009, Performance of tuberose (Polianthes tuberosa L.) cultivars in Goa. J. Hort. Sci., 4 (1): 76-77.

Shiramagond, 1997, Evaluation of varieties in gladiolus under Ghataprabha Command Area. M. Sc (Agri) Theisis. Univ. of Agril. Sci., Dharwad.

Singh, A. K., Kumar, A. and Ghimiren, R., 2013, Performance of Indian and exotic varieties of gladiolus under eastern Uttar Pradesh conditions. The Asian J. Hort., 8 (1): 191- 194.

Singh, K. P. and Singh, M. C., 2013, Evaluation of double petalled cultivars of tuberose (Polianthes tuberosa L.) under Delhi condition. The Asian J. Hort., 8 (2): 512-514.

\section{How to cite this article:}

Bindiya C. Naik, B. S. Kamble, Shantappa Tirakannanavar and Savita Parit. 2018. Evaluation of Different Genotypes of Tuberose (Polianthes tuberosa L.) for Growth, Flowering and Yield Characters. Int.J.Curr.Microbiol.App.Sci. 7(07): 4135-4141. doi: https://doi.org/10.20546/ijcmas.2018.707.482 